\title{
Impact of Board Composition on Financial Performance of Commercial Banks in Ethiopia
}

\author{
Addisu Gemeda Edeti, Mahesh Chand Garg \\ Haryana School of Business, Guru Jambheshwar University of Science and Technology, Hisar, India \\ Email address: \\ addisugemeda@gmail.com (A. G. Edeti),mc_garg@yahoo.com (M. C. Garg) \\ To cite this article: \\ Addisu Gemeda Edeti, Mahesh Chand Garg. Impact of Board Composition on Financial Performance of Commercial Banks in Ethiopia. \\ International Journal of Economic Behavior and Organization. Vol. 9, No. 3, 2021, pp. 49-56. doi: 10.11648/j.ijebo.20210903.12
}

Received: July 3, 2021; Accepted: July 27, 2021; Published: August 18, 2021

\begin{abstract}
The major objective of the present study is to examine the impact of internal and external board composition on financial performance of commercial banks in Ethiopia. The samples selected for the present study are twelve commercial banks based on ten years financial report for the period of 2009-2018. Both primary and secondary data collection methods employed for the study. Primary data for corporate governance (board compassion) which is independent variable and secondary data for bank financial performance Return on Asset (ROA), Return on Equity (ROE), and Net Interest Margin (NIM) dependent variables of the present study. Explanatory type of study with a quantitative approach was employed to analyze the collected data. Both descriptive and econometric analyses are used for the current study. Descriptive analysis includes mean, maximum, minimum, and standard deviation, whereas, econometric model includes correlation and regression analysis. Fixed effect and random effect econometric analysis has been made using Eviews-9 Software. The present study shows that there is a linear relationship between board compassion (independent variable) and commercial banks financial performance as measured by Return on Assets (ROA). From this, the researcher reveals that there is a positive and statistically significant relationship between board composition and Return on Assets (ROA). There is negative and statistically insignificant relationship between board composition and Return on Equity (ROE) of commercial banks in Ethiopia. Board Composition is negatively correlated with Net Interest Margin (NIM) and statistically significant at $5 \%$ level of significant. The present study concludes that the higher the board composition leads to better financial performance as measured by Return on Assets (ROA), but in contrarily the higher the board composition of commercial banks in Ethiopia decreases the financial performance as measured by Return on Equity (ROE) and Net Interest Margin (NIM).
\end{abstract}

Keywords: Corporate Governance, Financial Performance, Board Composition, Commercial Banks

\section{Introduction}

The issue of corporate governance becomes international in the early 1980s. Corporate governance "plays a vital role for macro and micro economic stability for economic growth as well as society welfare. Therefore, international organizations give more attention and concern to this issue at the micro and macro levels. It is used to make a smooth relationship among shareholders, board of directors, and top management in determining the direction and performance of the corporation. It is also defined to include the structures, processes, cultures, and systems that engender the successful operation of organizations. The concept of corporate governance of banks and every large firm has been a priority on the policy agenda in the developed market economies for over a decade. The concept is gradually warming itself as a priority in the African continent.

Tomar and Bino [28] state that "corporate governance is about putting in place the structure, processes, and mechanisms that ensure the firm is being directed and managed in a way that enhances long-term shareholder value through accountability of managers and enhancing firm performance. In other words, through such structure, processes, and mechanisms, the well- known agency problem (which results from the separation of ownership from management and leads to a conflict of interests within the firm) may be addressed so that the interests of managers can be aligned with those of the shareholders". 
Now-a-days, a most "of the shareholders in the firm are seeking to be the board of directors to account for the financial performance of their organization in the business environment. The failure of substantial corporations around the world has paid their attention to the performance and behavior of the board of directors of an organization. Board of directors, found on the top management of the organization, is held responsible for the strategic direction that the organization takes. Effective corporate governance is having very crucial background and affects the success of entrepreneurship.

Various researchers in many countries have made exploration on this area by seeing the importance and the current issues of financial performance in the banking sector.

A number of existing researches has focused on developed countries. However, the importance of understanding the interaction of corporate governance in developing countries is also necessary, because globalization, international investment, and international trade require improved corporate governance, which will enable developing countries to achieve high and sustainable rates of growth by attracting more investment.

Corporate "governance helps in bringing transparency and reliability to business activities in a number of ways. Corporate governance involves harmonizing the interests of a company's stakeholder such as shareholders, senior management executives, customers, suppliers, financiers, the Government, and the community. Therefore, it helps companies to make faithful to investors and society, promote financial capability by constructing a long-term investment opportunity for engaging parties that is why, calls value creation and corporate governance go hand in hand".

Aggarwal [4] argues that "well-organized governance in a corporation fosters good financial performance. According to Fama and Jensen [10], the separation of ownership and control in modern corporations leads to an agency problem where the agent operates the firm in line with their own interests instead of shareholders. The need for corporate governance arises from these potential conflicts of interest among stakeholders such as shareholders, board of directors, and managers in the" corporate structure.

The "main focus of this study is to examine the impact of corporate governance on the financial performance of commercial banks in Ethiopia. Therefore, the researcher attempts to identify the relationship between corporate governance structure and financial performance of sample commercial banks in Ethiopia. This emphasizes the importance of legal rules and the quality of their enforcement. In Ethiopia, currently the banking sector has become a favorite area of business for many investors and other stakeholders such as creditors, customers, Government and the public as a whole. However, the banking sector in Ethiopia is under good progress, still it is characterized by many problems such as limited range of services, absence of capital markets, and the sector largely remains closed to foreign" investors.

\section{Empirical Review of Related Literature}

According to proponents of agency theory, "effective boards should be made up of a majority of outside directors, who are not employed by the company and have no relation to its employees". The "structure of a board of directors reveals information about the quality of the firm's management and the extent of checks and balances on managerial decisions. Boards are often made up of inside and independent (outside) members. Insiders are major shareholders, founders and executives. Independent directors do not share the draws of the insiders, but they are chosen because of their experience in managing or directing other large" companies.

Board "composition is the sum of internal and external board members in corporate governance. External director is one who has no accountability for day-to-days functions of the company but involves in making strategic decisions for the firms' implementation. Thus, outside directors do not hold other offices in the firm apart from directorship. Board is the responsible body of the firm in charge of formulating strategic decisions for implementation by management, how these board members are represented and by whom they nominate and its consequences on the financial performance of firms' is a hot issue for different" researchers.

According to agency theory, "independent directors facilitate effective oversight on board practices as they are able to produce more objective judgments on management performance. This occurs because these managers are less involved in the company's operations and thus they are less dependent on control exerted by the Chief Executive Officer. The study made by Lehn et al. [19] found that there is a positive link between firm performance and board composition. However, Matsa and Miller [20] conclude that there is no relationship between board composition and firm performance. The studies made by Fosberg [11] also show similar results. Rosenstein and Wyatt [25] found that if the engagement of external directors is properly differentiated, it led to a rising up in shareholder wealth. Naciti [21] concluded that the relationship between non-executive members seated in the supervisory board and financial performance measured by Return on Asset (ROA) and Return on Equity (ROE) are negatively correlated. Shungu et al. [26] reveals that there is an insignificant negative relationship between board independence and Return on Asset (ROA) and Return" on Equity (ROE). The studies made by Ene and Bello. [9], Tachiwou [28], and Gebregeorgs and Kaur [12] concluded that there is a significant positive relationship between board composition and financial" performance.

The studies conducted by Dalton et al [8] and Wale [30] state that there is a negative correlation between proportion of outside directors and firms' performance. According to Choi and Hasan [7] independent outside board members are more likely to be ineffective in monitoring complex institutions having high potential growth. Rhode and Pack 
(24) reveals that independent boards of directors are good quality monitors but cannot put in economic value to the firms.

Previous evidence found in studies made by Raheja [23], Bohren and Strøm [6], Guest [13], Lehn et al. [19], and Fosberg [11], among others, argue that the structure and composition of the board are determined by the characteristics of the company, its environment, its information needs, and the possible agency conflicts it faces. Board independence and firm performance reveal a positive relationship, which meant that boards of companies that had a higher number of independent directors generally showed better performance results in terms of profitability. The reason for the same is due to the presence of an unbiased opinion in the running of the company. Outside directors tend to provide their expert opinion which is often independent of any vested interest in the company, thereby ensuring better overall corporate governance.

The importance of "board composition in corporate governance is widely debated that external independent directors may increase economic value to the firm. Previous studies by Adams et al. [3] and Abdulazeez et al. [1] revealed that appointing external independent directors affects positively the performance of firms, the reason is independent directors are not engaged in illegal acts. In contrast to the above findings, Kingdom [17] concluded that adding separate independent directors cannot diminish a firm's illegal acts. According to Sahu, and Manna [26], the firm with nonexecutive directors causes decreasing agency problems and better position of owners" and manager interest.

Rosenstein and Wyatt [25] found that "when an additional external director is placed, the firms' share price is rising up. In contrast, Adams and Mehran [2], and Zulkafli and Samad [31] disclosed that there is an insignificant relationship between board composition and firm performance of US and Asian banks respectively. Similarly, Choi and Hasan [7] using efficiency measures in addition to traditional profitability indicators found no significant relationship between the numbers of outside board directors and bank performance for US and Korea respectively. Ene and Bello [9] also confirmed that board composition has no significant influence on return on assets and return on equity, although they found a positive association between Tobin's Q and board" composition.

Matsa and Miller [20] argued that there is a powerful operational and strategic advantage related to the higher amount internal on corporate boards' an enhanced pledge to the organization produced by full-time employ attached with intimate knowledge of applicable environments results in a more effective board level decisions. Fosberg [11] found that firms with a large percentage of independent nonexecutive directors on their board are not characterized by better performance as measured by the firms' ROE.

The studies conducted by Hadlock and James [15], Bhagat and Bolton [5]. And Johl et al [16] confirmed that there is no relation between the independence of board members and the firm's performance. There are numerous benefits to board heterogeneity as examined by a combination of executive and independent non-executive managers because of enhanced conclusion making arising from quantity information although this would come at a substantial cost. Based on the above studies it can be concludes that there is lack of consistency in the finding of the relationship between board composition and firm's financial" performance.

\section{Research Methodology}

The methodology of every research work includes the research design, sampling techniques and sources of data, methods of data collection, and methods of data analysis. It is the heart of the study. The quality of every study depends on the methodology applied for the particular study. Therefore, methodology used for the purpose of study must be thoroughly chosen to minimize any chances of bias.

\subsection{Research Design}

A research design is the arrangement of conditions for the collection and analysis of data in a manner that aims to combine relevance to the research purpose. The research design is the conceptual structure within which the research is conducted. It constitutes the blueprint for the collection, measurement, and analysis of data. As such, the design includes an outline of what the researcher will do from writing the hypothesis and its operational implications to the final analysis of the data Kothari [18].

The choice of research design depends on the objectives of the research to answer the research questions in the research problem. Therefore, explanatory type of study with a quantitative approach was employed to analyze the collected data. According to Gujarati [14], explanatory research is devoted to finding causal relationships between dependent and independent variables. Since the research is a cause and effect type, it is more appropriate to use explanatory research type. Panel data analysis which is the combination of crosssectional and time series data is used for the present study.

\subsection{Population of the Study}

According to Ngechu [22], the target population entails an entire group of persons or things which have similar features which are preferred by the investigator. Target population consist of a group of entities or elements which might be considerable than or distinct from the sampled groups from which the researcher draws conclusions about the interested population. According to data from National Bank of Ethiopia, there are 18 banks in Ethiopia as on 2020. Among these, one bank is Development Bank of Ethiopia and the remaining 17 banks are commercial banks. Therefore, the present study's target population is all commercial banks in Ethiopia.

\subsection{Sample and Sampling Technique}

In research terms, a sample is a group of people, objects, or items that are taken from a larger population for 
measurement. The sample should be representative of the population to ensure that we can generalize the findings from the research sample to the population as a whole. Accordingly, the researcher has been select 12 commercial banks from a total of 17 commercial banks. The two types of sampling techniques are probability sampling techniques and non-probability sampling techniques. Probability sampling involves random selection, allowing a researcher to make strong statistical inferences about the whole group. This sampling method has equal chance for the total population to be sample. Whereas non-probability sampling involves non-random selection based on convenience or purposively or other criteria, allowing a researcher to easily collect data and has no equal chance for target population to be sample.

The present study used a non-probability sampling technique which is purposively based on ten years audited financial report they have for the years 2009-2018. Therefore, twelve commercial banks are the sample size for the present study. Accordingly, the selected commercial banks Commercial Bank of Ethiopia (CBE), Awash International Bank (AIB), Dashin Bank (DB), Oromia International Bank (OIB), Cooperative Bank of Oromia (COOP), Buna International Bank (BIB), Abysinya Bank (AB), Nib International Bank (NIB), Lion International Bank (LIB), Wegagen Bank (WB), Brihan International Bank (BIB), and Zemen Bank (ZB).

\subsection{Source of Data and Methods of Data Collection}

The process of acquiring, collecting, extracting, and storing a large volume of data, whether structured or unstructured, for subsequent phases of data analysis is known as data collection. The majority of the data collected is of two types: qualitative data, which is a collection of non-numerical data such as words, and sentences that focuses on the group's behavior and actions, and quantitative data, which is numerical data that can be calculated using various scientific tools and sampling data. The present study employed quantitative data for both corporate governance variables (independent variables) and financial performance variables (dependent variables).

Both primary and secondary data collection methods are used in the present study. Primary data using questionnaires to survey for the corporate governance variables of selected commercial banks in Ethiopia obtained from managers and secretory of each sampled commercial banks whereas secondary data on financial performance of commercial banks in Ethiopia (audited financial statement report) obtained from National Bank of Ethiopia. Therefore, the present study was employed a quantitative approach and used both primary and secondary sources of data.

\subsection{Hypothesis of the Study}

On the basis of the empirical literature on corporate governance (board composition) and bank financial performance, the following hypotheses have been tested. (Ha: Alternative hypothesis)

Ha1: There is a positive and significant relationship between board composition and financial performance as measured by Return on Assets (ROA) of commercial banks In Ethiopia.

Ha1: There is a positive and significant relationship between board composition and financial performance as measured by Return on Equity (ROE) of commercial banks In Ethiopia.

Ha1: There is a positive and significant relationship between board composition and financial performance as measured by Net Interest Margin (NIM) of commercial banks In Ethiopia.

\subsection{Method of Data Analysis}

The present study has used both descriptive and econometrics analysis. Descriptive analysis includes mean, maximum, minimum, and standard deviation, whereas, econometric model includes correlation and regression analysis. Fixed effect and random effect econometric analysis has been made using Eviews-9 Software.

\subsection{Model Specification}

Due to the combination of cross-sectional data and timeseries data, the Ordinary Least Square (OLS) regression technique is unsuitable analysis. The appropriate method of analysis involved panel data regression techniques. The core advantage of working with panel data is that we will be able to control for individual-specific, time-invariant, unobserved heterogeneity, the presence of which could lead to bias in standard estimators like OLS.

There are two frequently used estimation techniques for panel data regression. These are the Fixed Effects Model (FEM) and the Random Effect Model (REM) (Gujarati, 2003). The Fixed effect model assumes that the slope coefficients of the explanatory variables are all identical for all firms. The intercept in the regression model is allowed to differ among individual firms in recognition of the fact that each individual or cross-sectional unit may have some special characteristics of its own. To take into account the differing intercepts, dummy variables may be used. The fixed effect model using dummy variables is known as the Least-Squares Dummy Variable (LSDV) model Gujarati [14] The Random effect model is sometimes known as the Error Component Model (ECM). In ECM, it is assumed that the intercept of an individual unit is a random drawing from a much larger population with a constant mean value. The individual intercept is then expressed as a deviation from this constant mean value.

The researcher adopted a general panel regression model as follows:

$$
\text { Yit }=\alpha+\Sigma \beta X i t+\varepsilon i t
$$

Where, 
Yit $=$ the value of dependent variables $(\mathrm{ROA}, \mathrm{ROE}$, and NIM)

$\alpha=$ the constant value

$\beta=$ the intercept

$\mathrm{X}_{\mathrm{it}}=$ the explanatory variable $(\mathrm{BCO})$

$\varepsilon=$ the error term

Hence,

Model 1: ROAit $=\alpha+\beta_{1}$ BCOit + eit

Model 2: $\mathrm{ROE}_{\text {it }}=\alpha+\beta_{1} \mathrm{BCO}$ it + eit

Model 3: NIMit $=\alpha+\beta_{1}$ BCOit $+\varepsilon i t$

Dependent variables used in model are:

$\mathrm{ROA}=$ Return on asset to the bank and period $\mathrm{t}$

$\mathrm{ROE}=$ Return on equity for the bank and period $\mathrm{t}$

$\mathrm{NIM}=$ Net interest margin for the bank period $\mathrm{t}$

Independent variable used in model is:

$\mathrm{BCO}=$ Board composition.

Return on Asset (ROA), measures how efficient a company's management is generating earnings from their economic resources or assets on their balance sheet. It is shown as a percentage, and the higher the number, the more efficient a company's management is at managing its balance sheet to generate profits.

It can be calculated using the formula: ROA = Net Income X 100 Average total Assets.

Return on Equity (ROE), measures the profitability of a corporation in relation to stockholders' equity. It is a ratio that provides investors with insight into how efficiently a company (or more specifically, its management team) is handling the money that shareholders have contributed to it. The higher the ROE, the more efficient a company's management is at generating income and growth from its equity financing.

It is calculated using the formula $\mathrm{ROE}=$ Net income $\mathrm{X} 100$ Shareholders' equity.

Net Interest Margin (NIM) is a measure of the difference between the interest income generated by banks and the amount of interest paid out to their lenders. It shows how successful a bank's investment decisions are compared to its debt situation, relative to the amount of their interest earning assets (Loans and Advances). It is usually expressed as a percentage of what the financial institution earns on loans in a specific period and other assets minus the interest paid on borrowed funds divided by the average amount of assets on which it earns income in that period (the average earning assets). The NIM variable is defined as the net interest income divided by total earnings assets Loans and Advances (Gul, \& Zaman, 2011).

It is calculated using the formula NIM $=$ Net interest income X 100 Average asset.

\section{Result and Discussion}

\subsection{Descriptive Analysis}

The major aim of this chapter is to discuss the results using descriptive statistics. Descriptive statistics is the name given to a kind of data analysis that helps to explain, illustrate, or summarize data in an understandable way so that patterns might emerge. Descriptive statistics summarizes the main features of the study variables in terms of mean, maximum, minimum, and standard deviation.

Mean; it is the most commonly used method to describe the central tendency. It is calculated by adding all values and then divided by the number of values.

Minimum and maximum: minimum is the minimum value of the data and maximum is the maximum value of the data.

Standard deviation: standard deviation is the accurate estimation of dispersion. It shows the relationship of the data with the mean of the sample.

Table 1. Summary of Descriptive Statistics for Dependent variables.

\begin{tabular}{llllll}
\hline Variables & Observations & Mean & \multicolumn{2}{l}{ Maximum Minimum } & Std. Dev. \\
\hline ROA & 120 & 3.086 & 6.700 & 0.000 & 0.973 \\
ROE & 120 & 24.841 & 77.710 & 0.000 & 12.169 \\
NIM & 120 & 5.198 & 14.000 & 1.200 & 2.484 \\
\hline
\end{tabular}

Source: Computed results by Eviews- 9 .

Table 1 shows that the mean of financial performance of commercial banks measured by ROA is 3.086 percent (mean $=0.031$ ) with minimum 0.000 percent and maximum 6.700 percent. The standard deviation result of 0.973 indicates that for the sample commercial banks ROA varies by 0.973 from the average value of 3.086 .

As shown on table 1 , the mean value of ROE is 24.84087 percent (mean $=0.248$ ) with maximum 77.710 percent and minimum value of 0.000 percent and standard deviation of 12.169 This implies that the sample commercial banks in Ethiopia on average earned 24.841 percent of each birr invested in shareholders' equity and the standard deviation result shows that it varies by 12.169 from the average value of 24.841. The NIM which is measured by net interest income divided by average asset shows a mean value of 5.198 percent (mean $=0.052$ ) with maximum 14.000 percent and minimum 1.200 percent. The standard deviation 2.484 percent from its average value shows that NIM differs by 2.484 . This implies that the sample banks on average earned 5.198 percent net interest income of the total loan and advances. Meanwhile, NIM reflects how the bank covers its cost of service and the profitability of the bank, the higher the NIM show, the higher the banks profit and the more stable the bank is.

Table 2. Summary of Descriptive Statistics for independent variables.

\begin{tabular}{llllll}
\hline Independent Variables & Observation & Mean & Maximum & Minimum & St. Deviation \\
\hline $\mathrm{BCO}$ & 120 & 0.550 & 1.000 & 0.000 & 0.499 \\
\hline
\end{tabular}

Source: Computed eviews-9 results. 
members, internal and external, and has the mean value 0.550 which suggests that commercial banks in Ethiopia have fifty five percent independent directors which implies banks take independent and effective decision making with a maximum percent of 1.000 and minimum percent of 0.000 . This indicates that 55 percent of the board members are external and the remaining 45 percent of the board members are internal for the present study.

\subsection{Result of Correlation Analysis}

A correlation coefficient in statistics is a quantitative assessment that measures both the direction and the strength of this tendency to vary together. There are different types of correlation that you can use for different kinds of data. For this study, the researchers used the most common type of correlation Pearson's correlation coefficient. The greater the absolute value of the correlation coefficient, the stronger the relationship with the variables (dependent and independent) is strength.

Table 3 shows as there is a linear relationship between the financial performance of commercial banks in Ethiopia measured by Return on Assets (ROA), Return on Equity
(ROE), and Net Interest Margin (NIM) and corporate governance the combination of internal and external board members (board composition).

Table 3. Correlation analysis of ROE, ROA \& NIM with board composition

\begin{tabular}{lllll}
\hline & ROE & ROA & NIM & BCO \\
\hline ROE & 1.000 & & & \\
ROA & 0.477 & 1.000 & & \\
NIM & -0.245 & -0.284 & 1.000 & \\
BCO & 0.004 & 0.190 & 0.030 & 1.000 \\
\hline
\end{tabular}

Source: Computed from E-views- 9.

\subsection{Result of Regression Analysis}

Regression is "a statistical method used in finance, investing, and other disciplines that attempts to determine the strength and character of the relationship between one dependent variable (usually denoted by $\mathrm{Y}$ ) and a series of other variables (known as independent variables). The dependent variables for this study are the financial performance of commercial banks in Ethiopia measured by ROE, ROA, and NIM and the independent variable is Board Composition (BCO).

Table 4. Fixed effect regression results using ROE as a proxy of financial performance.

\begin{tabular}{|c|c|c|c|c|}
\hline \multicolumn{5}{|c|}{ Dependent variable ROE } \\
\hline \multicolumn{5}{|c|}{ Method panel EGLS (Cross section weight) } \\
\hline \multicolumn{5}{|c|}{ Sample $2009-20118$} \\
\hline \multicolumn{5}{|c|}{ Period included 10} \\
\hline \multicolumn{5}{|c|}{ Cross section included } \\
\hline \multicolumn{5}{|c|}{ Total panel (unbalanced) observation 120} \\
\hline Variable & Coefficient & Std. Error & t-Statistics & Prob. \\
\hline $\mathrm{C}$ & 0.129 & 0.042 & 3.091 & 0.003 \\
\hline R-Squared & 0.425 & Mean dependent var. & & 0.035 \\
\hline Adjusted R squared & 0.328 & S. D. dependent var. & & 0.013 \\
\hline SE. of regression & 0.007 & Sum squared resid & & 0.004 \\
\hline F-Statistic & 5.419 & Durbin-Watson stat & & 1.615 \\
\hline Prob.(F-Statistic) & 0.000 & & & \\
\hline
\end{tabular}

Source: Computation of E-Views-9 result.

Board composition in the present study concerned on the combination of internal and external which is measured by dummy variable 1 for there is board composition and 0 for no board composition. From the fixed effect regression result in Table 3 shows that insignificant relationship between $(\beta=-$ $0.000484 \mathrm{P}=0.733$ ).

Table 5. Fixed effect regression results using ROA as a proxy of financial performance.

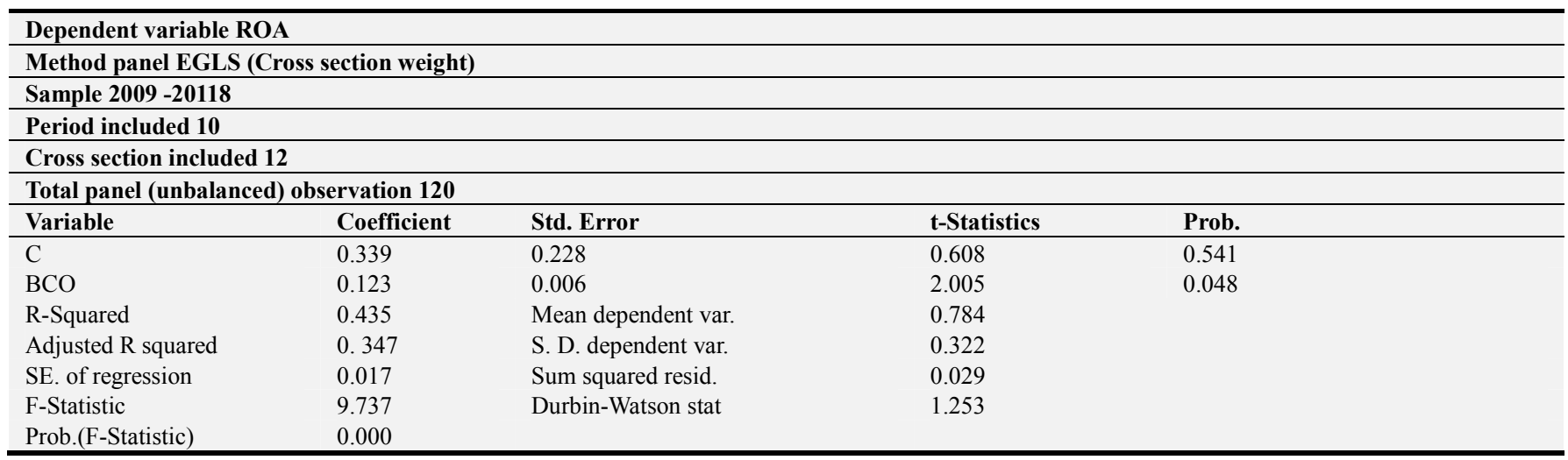

Source: Computation of E-Views-9 result. 
From the fixed effect regression result in Table 5 the coefficient of the BCO is 0.0122 and its p-value is 0.048 . From this, the researcher reveals that there is a positive and statistically significant relationship between board composition and return on assets This indicates holding other independent variables remain constant as board composition increased by one, the return on assets on average increased by 1.22 percent. This is due to the fact that an outside director is a member of a company's board of directors who is not an employee or stockholder in the company, in theory they are more likely to provide unbiased opinions. This finding in line with the previous researchers (Tornyeva and Wereko, 2012; Prowse, 1997; Bonn et al., 2004; Brancato et al., 2003; Timme et al., 1993; Fenn, et al., 1997).
As indicated in Table 5 the coefficient of board composition which is measured by the percentage of independent board members using dummy variable 1 , there is board composition and 0 there is no board composition for the selected commercial is -0.656 and the p-value is 0.019 . This figure indicates that board composition is negatively correlated with net interest margin and statistically significant at $5 \%$ level of significant. This interpretation is by holding all other independent variables remain constant as board composition increased by one unit, and the net interest margin decreased by 0.656 percent. The above findings consistent to the previous studies (Rashid, et al., 2010; Kesner et al., 1986).

Table 6. Fixed effect regression results using NIM as a proxy of financial performance.

\begin{tabular}{|c|c|c|c|c|}
\hline \multicolumn{5}{|c|}{ Dependent variable NIM } \\
\hline \multicolumn{5}{|c|}{ Method panel EGLS (Cross section weight) } \\
\hline \multicolumn{5}{|l|}{ Sample 2009 -20118 } \\
\hline \multicolumn{5}{|c|}{ Period included 10} \\
\hline \multicolumn{5}{|c|}{ Cross section included 12} \\
\hline \multicolumn{5}{|c|}{ Total panel (unbalanced) observation 120} \\
\hline Variable & Coefficient & Std. Error & t-Statistics & Prob. \\
\hline $\mathrm{C}$ & -54.189 & 12.982 & -4.174 & 0.001 \\
\hline $\mathrm{BCO}$ & 0.655 & 0.276 & -2.375 & 0.019 \\
\hline R-Squared & 0.410 & Mean dependent var. & 5.198 & \\
\hline Adjusted R squared & 0.448 & S. D. dependent var. & 1.323 & \\
\hline SE. of regression & 0.958 & Sum squared resid & 93.600 & \\
\hline F-Statistic & 7.364 & Durbin-Watson stat & 1.408 & \\
\hline Prob.(F-Statistic) & 0.000 & & & \\
\hline
\end{tabular}

Source: Computation of E-Views-9 result.

\section{Conclusions}

The major aim of the present study is to examine the impact of board composition on financial performance as measured by Return on Assets (ROA), Return on Equity (ROE), and Net Interest Margin (NIM) of commercial banks in Ethiopia. Panel data analysis model is used for the study for ten years financial report 2009-2018. Secondary data is used to collect information about financial performance of commercial banks obtained from National bank of Ethiopia (NBE), and primary data is used to collect information about corporate governance (board composition) using questioners obtained from managers and secretory of sampled commercial banks. The present study reveals that there is insignificant relationship between board composition and financial performance as measured by Return on Equity (ROE) and a positive and statistically significant relationship between board composition and Return on Assets (ROA) and Net Interest Margin (NIM) at $5 \%$ level of significance. The correlation result shows on Table 3 there is no relationship between board composition and financial performance as measured by Return on Equity and linear relationship between Return on Asset (ROA) and Net Interest Margin (NIM).

\section{References}

[1] Abdulazeez, D. A., Ndibe, L., \& Mercy, A. M. (2016), Corporate governance and financial performance of listed deposit money banks in Nigeria, Journal of Accounting and Marketing, 5 (1), 1-6.

[2] Adams, R. B., \& Mehran, H. (2008), Corporate performance, board structure, and their determinants in the banking industry FRB of New York staff report, (330).

[3] Adams, R. B., Hermalin, B. E., \& Weisbach, M. S. (2010), The role of boards of directors in corporate governance: A conceptual framework and survey Journal of economic literature, 48 (1), 58-107.

[4] Aggarwal, P. (2013), Impact of corporate governance on corporate financial performance. IOSR Journal of Business and Management, 13 (3), 01-05.

[5] Bhagat, S., \& Bolton, B. (2008). Corporate governance and firm performance. Journal of corporate finance, 14 (3), 257273.

[6] Bohren, Ø., \& Strøm, R. Ø. (2010). Governance and politics: Regulating independence and diversity in the board room. Journal of Business Finance \& Accounting, 37 (9-10), 1281-1308. 
[7] Choi, S., \& Hasan, I. (2005). Ownership, governance, and bank performance: Korean experience. Financial Markets, Institutions \& Instruments, 14 (4), 215-242.

[8] Dalton, D. R., Daily, C. M., Johnson, J. L., \& Ellstrand, A. E. (1999). Number of directors and financial performance: A meta-analysis. Academy of Management journal, 42 (6), 674686.

[9] Ene, E. E., \& Bello, A. I. E. (2016). The effect of corporate governance on bank's financial performance in Nigeria. IOSR Journal of Business and Management, Vol. 18, No. 11, pp. 99107.

[10] Fama, E. F., \& Jensen, M. C. (1983). Separation of ownership and control. The journal of law and Economics, 26 (2), 301 325 .

[11] Fosberg, R. H. (1989). Outside directors and managerial monitoring. Akron Business and Economic Review, 20 (2), 24.

[12] Gebregeorgs, N., \& Kaur, H. (2017) Board Structure and Financial Performance: A study of state-owned service enterprises in Ethiopia.

[13] Guest, P. M. (2008). The determinants of board size and composition: Evidence from the UK. Journal of Corporate Finance, Vol. 14, No. 1, pp. 51-72.

[14] Gujarati, D. N., \& Porter, D. C. (2003). Basic econometrics (ed.). Singapore: McGrew Hill Book Co.

[15] Hadlock, C. J., \& James, C. M. (2002). Do banks provide financial slack?. the Journal of Finance, 57 (3), 1383.

[16] Johl, S. K., Kaur, S., \& Cooper, B. J. (2015). Board characteristics and firm performance: Evidence from Malaysian public listed firms. Journal of Economics, Business and Management, 3 (2), 239-243.

[17] Kingdom, U. (2016). Effect of Board Diversity on Corporate Governance Structure and Operating Performance: Evidence from the UK Listed Firms. Vol. 5, No. 80, pp. 67-80.

[18] Kothari, C. R. (2004). Research methodology: Methods and techniques. New Age International.

[19] Lehn, K. M., Patro, S., \& Zhao, M. (2009). Determinants of the size and composition of US corporate boards: 1935-2000. Financial management, 38 (4), 747-780.

[20] Matsa, D. A., \& Miller, A. R. (2013). A female style in corporate leadership? Evidence from quotas. American Economic Journal: Applied Economics, 5 (3), 136-69.

[21] Naciti, V. (2019). Corporate governance and board of directors: The effect of a board composition on firm sustainability performance. Journal of Cleaner Production, $237,117727$.

[22] Ngechu, M. (2004). Understanding the research process and methods. An introduction to research methods. Unpublished MBA Thesis, School of Business: University of Nairobi.

[23] Raheja, C. G. (2005). Determinants of board size and composition: A theory of corporate boards. Journal of financial and quantitative analysis, 283-306.

[24] Rhode, D. L., \& Packel, A. K. (2014). Diversity on corporate boards: How much difference does difference make. Del. J. Corp. L., Vol. 39, pp. 377.

[25] Rosenstein, S., \& Wyatt, J. G. (1990). Outside directors, board independence, and shareholder wealth. Journal of financial economics, 26 (2), 175-191.

[26] Sahu, T. N., \& Manna, A. (2013). Impact of Board Composition and Board Meeting On Firms' Performance: A Study of Selected Indian Companies. Vilakshan: The XIMB Journal of Management, 10 (2).

[27] Shungu, P., Ngirande, H., \& Ndlovu, G. (2014). Impact of corporate governance on the performance of commercial banks in Zimbabwe. Mediterranean journal of social sciences, $5(15), 93-93$.

[28] Tachiwou, A. M. (2016). Corporate governance and firms' financial performance of listed company in the West African Monetary Union (Wamu) Regional Financial Exchange. International Journal of Economics and Finance, Vol. 8, No. 8, pp. 212-221.

[29] Tomar, S., \& Bino, A. (2012). Corporate governance and bank performance: evidence from Jordanian banking industry. Jordan Journal of Business Administration, 8 (2), 353-372.

[30] Wale, L. E. (2017). Board Structure and Performance In Ethiopian Microfinance Institutions.

[31] Zulkafli, A. H., \& Samad, F. A. (2007). Corporate governance and performance of banking firms: Evidence from Asian emerging markets. In Issues in corporate governance and finance. Emerald Group Publishing Limited. 